\title{
1KEMAMPUAN PROBLEM SOLVING DALAM TIM MELALUI TEAM BUILDING PADA MAHASISWA KKN DI DAERAH NANGSRI KLATEN
}

\author{
Anna Febrianty Setianingtyas., S.Psi., M.Si., M.Psi., Psikolog
}

\begin{abstract}
Abstrak
Penelitian ini bertujuan meneliti kemampuan problem solving dalam tim mahasiswa melalui team building dalam kegiatan Kuliah Kerja Nyata (KKN) sebagai bentuk pengabdian kepada masyarakat yang wajib diikuti oleh mahasiswa program strata satu (S1)nya. Penelitian ini menggunakan metode penelitian kualitatif dengan pendekatan fenomenologi. Selama proses pelaksanaan Kulia Kerja Nyata, salah satu tugas yang harus dikerjakan adalah bekerja secara tim. Seorang mahasiswa sebagai insan akademis itu sendiri memiliki dua ciri yaitu: memiliki sense of crisis, dan selalu mengembangkan dirinya sehingga setiap proses penyelesaian masalah dengan mengikuti watak ilmunya yang diharapkan dapat memahami berbagai masalah yang terjadi dan terlebih lagi menemukan solusi-solusi yang tepat.
\end{abstract}

Kata kunci: problem solving, team building, mahasiswa, KKN

Pendahuluan

Kuliah Kerja Nyata merupakan proses pembelajaran bagi mahasiswa program strata satu (S1) yang dikembangkan melalui kegiatan pengabdian kepada masyarakat dalam kehidupan bermasyarakat sebagai bentuk pengabdian kepada Masyarakat, Kuliah Kerja Nyata (KKN) yang wajib diikuti oleh mahasiswa program strata satu (S1). Pelaksanaan KKN memiliki tujuan menumbuhkan empati dan kepedulian civitas akademika terhadap berbagai permasalahan yang dihadapi masyarakat dan pembangunan berkelanjutan yang dibutuhkan untuk mencerdaskan kehidupan bangsa dan mewujudkan kesejahteraan masyarakat. Kuliah Kerja Nyata (KKN) merupakan suatu kegiatan intrakurikuler yang memiliki tujuan memadukan pelaksanaan konsep Tri Dharma Perguruan Tinggi untuk berpartisipasi dalam pembangunan masyarakat di pedesaan melalui kerjasama dalam kelompok atau tim.

Kerja tim yang dilakukan mahasiswa memiliki susunan program kerja yang harus dikerjakan pada masa kepengurusan kemudian pada awal kepengurusan merupakan sebuah bentuk tanggung jawab yang harus dipikul oleh setiap individu sebagai konsekuensi dari statusnya sebagai anggota organisasi. Dalam proses berorganisasi, salah satu tugas yang harus dikerjakan adalah kerja kelompok atau bekerja secara tim. Tim adalah sekelompok orang yang sportif, sensitif, dan senang bergaul, serta mampu mengenali aliran emosi yang terpendam dalam tim dengan sangat

\footnotetext{
${ }^{1}$ Setianingtyas, Anna Febrianty. 2018. Kemampuan Problem Solving Dalam Tim Melalui Team Building Pada Mahasiswa KKN Di Daerah Nangsri Klaten. Laporan Penelitian
} 
jelas. Tim menghasilkan sinergi positif melalui usaha yang terkoordinasi. Usaha-usaha individual mereka menghasilkan satu tingkat kinerja yang lebih tinggi daripada jumlah masukan individual (Barron, 2000; Henkin \& Wanat, 1994; Staw, Sutton, \& Pelled, 1994). Penggunaan tim secara efektif menghasilkan potensi untuk menyelesaikan masalah dan bagi sebuah organisasi untuk membuahkan hasil yang lebih besar dan lebih unggul daripada kinerja individu jika tugas yang harus dilakukan menuntut keterampilan ganda (Cavaleri, Firestone, \& Reed, 2012; Henkin \& Wanat, 1994). Namun pada kenyataannya di dalam tim, sering sekali tidak semua anggota tim menjunjung tinggi nilai dan etika bekerjasama.

Problem solving merupakan bagian dari proses berpikir yang dibutuhkan dalam menyelesaikan segala permasalahan yang sedang dihadapi oleh seseorang. Problem solving melibatkan kompleks mental yang merupakan vasiasi dari keterampilan dan perilaku kognitif. Hal ini menunjukkan bahwa problem solving merupakan bagian dari keterampilan berpikir tingkat tinggi, seperti visualisasi, asosiasi, abstraksi, komprehensi, manipulasi, analisis, sintesis, dan generalisasi (Gorofalo dan Lester, 1985 dalam Kirkley, 2003). Problem solving team memiliki makna penyelesaian masalah dalam tim, di mana mahasiswa dapat menyelesaikan segala bentuk permasalahannya secara bersama-sama yang merupakan permasalahan dalam tim KKNnya. Oleh karena itu peneliti merasa perlu melakukan penelitian ini pada mahasiswa strata satu menjelang semester akhirnya di Universitas Widya Dharma Klaten yang sedang melaksanakan kegiatan KKN.

\section{Metode Penelitian}

Penelitian ini menggunakan metode penelitian kualitatif dengan pendekatan fenomenologi yang fokusnya adalah pengalaman individu ketika menyelesaikan masalah bagi mahasiswa didalam proses terbentuknya tim selama KKN di Nangsri, Klaten. Dengan demikian, melalui penelitian ini dapat dipahami essensi pengalaman menyelesaikan masalah yang dialami oleh beberapa individu, tentang konsep atau fenomena tertentu dengan mengeksplorasi struktur kesadaran manusia bagi mahasiswa dalam menghadapi permasalahan-permasahannya.

\section{Hasil dan Diskusi}

Problem solving merupakan bagian dari proses berpikir yang dibutuhkan dalam menyelesaikan segala permasalahan yang sedang dihadapi oleh seseorang. Problem solving melibatkan kompleks mental yang merupakan vasiasi dari keterampilan dan perilaku kognitif. Hal ini menunjukkan bahwa problem solving merupakan bagian dari keterampilan berpikir tingkat 
tinggi, seperti visualisasi, asosiasi, abstraksi, komprehensi, manipulasi, analisis, sintesis, dan generalisasi (Gorofalo dan Lester, 1985 dalam Kirkley, 2003). Problem solving team memiliki makna penyelesaian masalah dalam tim, di mana mahasiswa dapat menyelesaikan segala bentuk permasalahannya secara bersama-sama yang merupakan permasalahan dalam tim KKNnya. Oleh karena itu peneliti merasa perlu melakukan penelitian ini pada mahasiswa strata satu menjelang semester akhirnya di Universitas Widya Dharma Klaten yang sedang melaksanakan kegiatan KKN.

Matlin (1989) mengemukakan bahwa dalam memecahkan masalah, ada baiknya memperhatikan aspek-aspek dari masalah, yaitu: 1. Kondisi nyata yang dihadapi, misalnya seorang mahasiswa yang tidak mampu memimpin sebuah tugas karena kurang bisa melakukan koordinasi dan komunikasi yang kurang terbuka dengan anggota timnya. 2. Kondisi yang diinginkan, misalnya mahasiswa tersebut di atas menginginkan bisa ada bentuk koordinasi dan komunikasi tim bersama teman-temannya, 3 . Aturan atau batasan yang ada, misalnya si mahasiswa tersebut memegang teguh nilai, bahwa ia tidak boleh memaksakan ketidakmampuannya dalam mengkoordinir tugas yang seharusnya menjadi tanggungjawabnya dengan mencari kesalahankesalahan yang melanggar norma, seperti menuduh atau mengkambinghitamkan salah seorang anggota timnya. Dengan mempertimbangkan ketiga hal tersebut di atas akan membantu seorang individu dalam menentukan pemecahan masalah seperti apa yang akan dilakukan. Dalam contoh di atas, si mahasiswa tersebut mungkin akan berusaha bisa bersikap terbuka dalam berkomunikasi dan belajar menjadi kooperatif lagi dalam timnya yang disesuaikan dengan kemampuan anggota timnya. Pemecahan masalah merupakan keterampilan kognitif yang bersifat kompleks, dan mungkin merupakan kemampuan paling cerdas yang dimiliki manusia (Chi \& Glaser dalam Matlin, 1989).

\section{Daftar Pustaka}

